症例

\title{
胆囊捻転症の 1 治験例
}

県西部浜松医療センター外科

\begin{tabular}{|c|c|c|c|c|c|c|c|c|c|c|c|}
\hline \multicolumn{12}{|c|}{ 県西部浜松医療センター外科 } \\
\hline & 宇 & 野 & 武 & 治 & 内 & 村 & 正 & 幸 & 脇 & 慎 & 治 \\
\hline & 木 & 田 & 栄 & 郎 & 神 & 田 & 和 & 弘 & 水 & 町 信 & 行 \\
\hline & 山 & 田 & & 護 & 矢 & 次 & & 䓔 & 閏 & 谷 & 洋 \\
\hline \multirow{3}{*}{ 同 } & 鈴 & 木 & 昌 & 八 & 岡 & 田 & 朋 & 久 & & & \\
\hline & 病理 & & & & & & & & & & \\
\hline & 岡 & 本 & 一 & 也 & & & & & & & \\
\hline
\end{tabular}

\section{ACUTE TORSION OF THE GALLBLADDER}

Takeji UNO, Masayuki UCHIMURA, Shinji WAKI, Hideo KIDA, Kazuhiro KANDA, Nobuyuki MIZUMACHI, Mamoru YAMADA, Takashi YATSUGI, Hiroshi NEYATANI,

Shohachi SUZUKI and Tomohiro OKADA

Hamamatsu Medical Center. Department of Surgery Kazuya OKAMOTO

Hamamatsu Medical Center. Department of Pathology

胆衰捻転症は急激な胆衰の捻転によって，血行の遮断と胆衰の壊疽性变化をきたす胆 道系のらちでは比較的稀な疾患である. したがって緊急手術が絶対適応となる．最近わ れわれは本症の 1 例を経験した。 87踻, 女性で腰椎側弯を有し, 突然の右上腹部激痛, 黄㾝のない右上腹部腫瘤触知など，その臨床経過および超音波検査により急性胆衰炎を

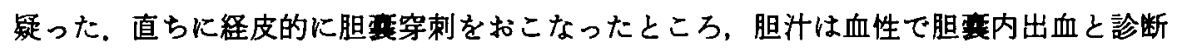
し, 緊急手術を施行した. 術中本症と判明し, 胆摘術を扢こなった. 術後は一時期麻疸 性イレゥスを呈したが，術後 6 週間で全治退院した症例である.

文献的に集計した本邦125例についてみると,術前に本症と診断しえた症例は 2 例のみ で，超音波検查，経皮的胆亯穿刺造影等の補助診断法によって術前に診断しえた例であ る.したがって術前診断に際しては, 本症の存在を念頭におくと共に, 上記の補助診断 法を有効に利用すべきである。また好発年齢が高龄であるにすかかわらず，手術による 予後が良好でしかも胆摘術が容易であることからる積極的に手術がなされるべきと考え る.

索引用語：胆震捻転症

はじめに

胆道疾患のらちで比較的まれな疾患に胆震捻転症が ある．本症は特徽的臨床所見を欠くことから，術前診 断が困難であり，手術により初めて本症と診断される

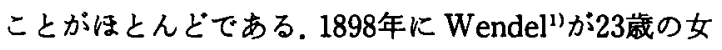
性例を報告して以来, 欧米では300余例が報告され，本 邦では1932年横山 ${ }^{2)}$ の59歳女性例の報告以来125例が
報告されている，われわれは最近87歳老女で開腹によ り胆震捻転症と判明し，手術的に治䈍せしめた 1 例を 経験したので若干の考察を加えて報告する.

$$
\text { 症例 }
$$

症例：庄○き $\bigcirc, 87$ 歳, + 主訴：右季肋部痛 (疝痛).

既往歴，家族歴：特記すべきことなし。 
現病歴：昭和57年 3 月 9 日夕食後, 心窝部疝痛出現. 保存的緊急処置を受けた。翌日疼痛改善せず，右季肋 部に疼痛移動し，急性胆敦炎の診断のもとに紹介され 緊急入院した。

入院時所見：体格中，栄養普通，意識は明瞭であっ たが，顔貌は苦悶状を呈していたまた脊椎側弯を認 める。体温 $37.2^{\circ} \mathrm{C}$, 脈拍 $100 /$ 分, 血压 $144 / 72 \mathrm{mmHg}$, 眼 䀫および眼球結膜に貧血，黄疸ともになし，腹部は平 担であるが，右季肋部に手拳大で弾性緊満な腫瘤を触 知した。さ同部に圧痛と筋性防御を認めるが, Blumberg 徵候は伴わない.

梌查所見および診断：血液一般,生化学的検查では， 筫血なく白血球增多 $\left(18,000 / \mathrm{mm}^{3}\right)$ があり，肝機能で は T.bil. $1.40 \mathrm{mg} / \mathrm{dl}$, D.bil. $0.48 \mathrm{mg} / \mathrm{dl}$ と軽度上昇. GOT 40U, GPT 25U, Al-P 4.5U, serum Amylase 76 S-RU, T.P. $6.6 \mathrm{~g} / \mathrm{dl}$ と正常範囲内であった.

胸部 X-P で心肥大，右横隔膜举上を認め, 腹部 X-P 上，右上腹部に結石と思わせる石灭化像と右突出型の scoliosis を呈している(写真 1 )。超音波検査では胆裏 は著しく畽大し, 胆亚内腔に結石エコーが認められた。 以上より急性化膿性胆襄炎の疑いで，䅅皮的に胆变穿 刺を行なった，胆汁は血泩で胆垔内出血と診断し，開 腹的ドレナージ目的にて手術を施行した。

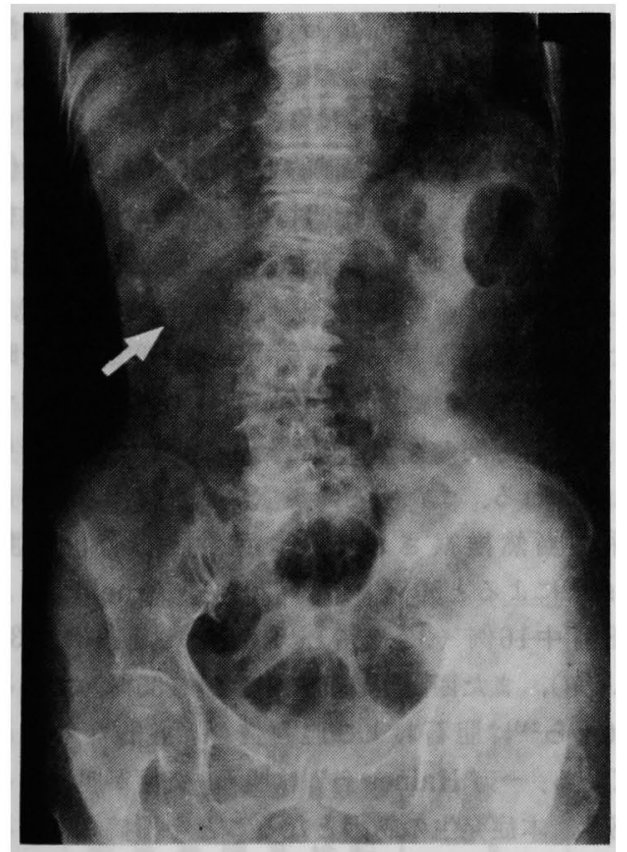

写严 1 腹部単純X線写真：右上腹部に結石と思われ る石灰化像（矢印）と腰椎側弯が認められる.
手術所見：気管内挿管 GOF 全麻下に, Körte 角状 切開にて開腹すると腹腔内には淡血性の腹水が中等量 認められた，触知した腫瘤は暗赤色壊死状の手挙大に 尰大した胆震で，肝床には固定されておらず，胆变管 のみで連なっている形で，頝部において反時計方向に $720^{\circ}$ 捻転していた. 捻転整復後, 容易に胆咅摘出術を施 行した。ささらに総胆管に軽度の払張をみとめるため, 総胆管切開をおこなった。

摘出標本：写真 2 の如く胆栾は $9.5 \times 7.0 \mathrm{~cm}$ で表面 は暗赤色を呈し，大部分壊死に陥っていた，内容は黒 色の血性胆汁が充满し, 最大 $15 \times 11 \mathrm{~mm}$ までの浮遊結 石（混成石）を 4 コ認めた。胆灌粘膜は黒色壊死状と なり，粘膜の脱落も認められた（写基 3 ）。

病理組織学的所見：胆咅は全層にわたり著明な出血 を伴なら壊死がみられ，一部分慢性胆变炎の像を呈し ていた。さらに動静脈の高度の拡張拈よび血栓形成が 認められた（写真 4 ）。

術後経過：術後は一時期, 麻瘏性イレウスになるも，

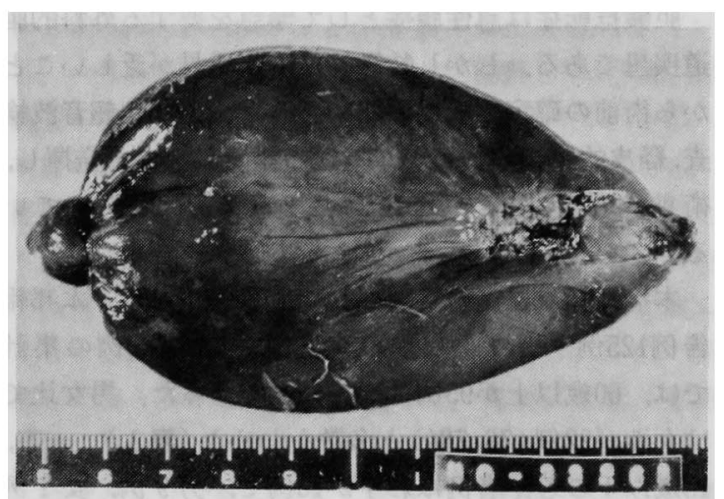

写真 2 摘出搮本（浆膜面）

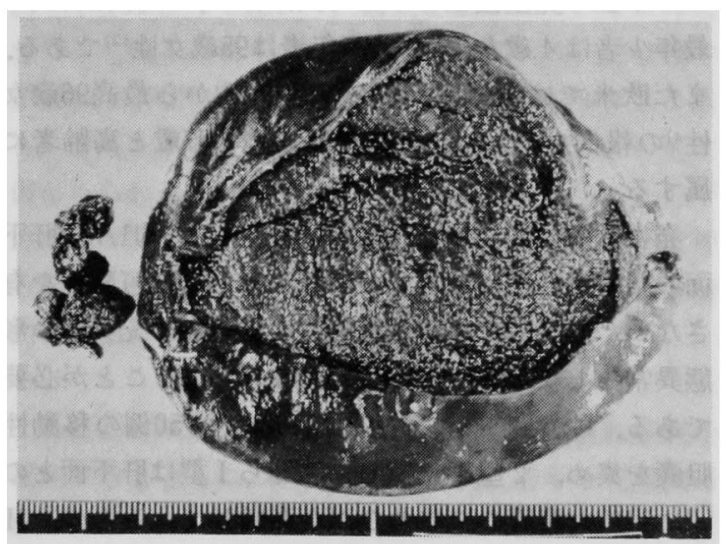

写真 3 摘出標本（粘膜面）と結石 


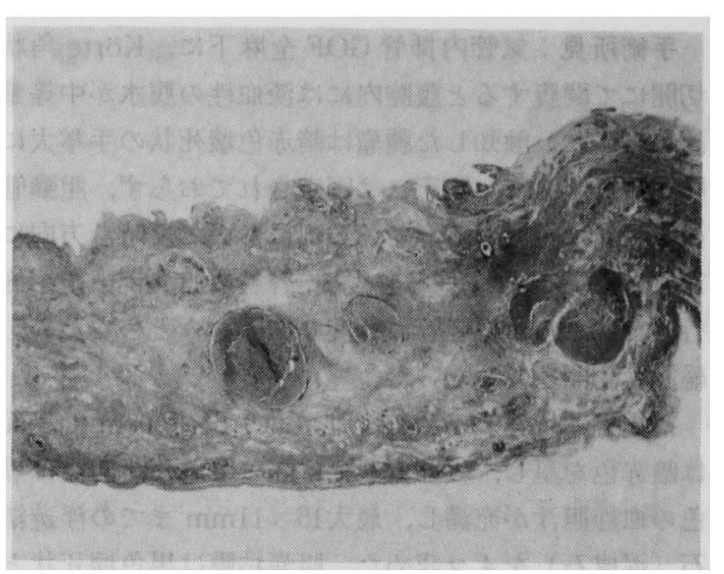

写真 4 胆䨢壁病理組織像（H.E. $\times 7.5 ） ：$ 粘膜面（写 真上方）は腺上皮の脱落を呈し，胆壁の肥厚と全 㬝に出血を伴ら壞死を認める. 血管は著明な拡張と 血栓形成をみる。

保存的療法にて軽快し， 6 週間で全治退院した。約 1 年経過した現在健在である。

\section{考案}

胆尨捻転症は急性腹症として緊急を要する外科的胆 道疾患である。しかし特徽的な臨床所見がそしいこと から術前の確定診断が困難である ${ }^{344)}$. 近年, 超音波検 查, 経皮的胆衰穿刺造影が本症の診断に威力を発揮し, 術前に確定診断のなされた 2 例が報告されてい $3^{5) 6)}$.

本症は60歳以上の高龄の女性に多くみられ，本邦報 告例125例 ${ }^{5)-10)}$ のち性別不明例を除く120例の集計 では，60歳以上が95例（79.2\%）であった。男女比で は女性が92例 (76.7\%) と多数をしめた（表 1)，一方， 15歳以下の若年者例はわずか10例で, 男 9 例, 女 1 例 と压倒的に男子に多く発生している。この男女比の違 いが本症の発生機転よりみて興味深い。本邦報告例の 最年少者は 4 歳女子 ${ }^{11)}$, 最高年者は95歳女性 ${ }^{12)}$ である。 また欧米では生後 6 時間の新生児133から最高96歳女 性4の報告をみる。われわれの症例も87歳と高龄者に 属する。

発生機序に関しては, 胆基はその全周の約 $1 / 3 か$ 肝下 面の胆衰窝に泌に付着しており，ほとんど可動性を有 さない：したがって胆貫捻転症の発生には先天性の形 態異常として floating gallbladderであることが必要 である. Gross ${ }^{(4)}$ はこの可動性を有する50例の移動性 胆襄を集め， 2 型に分類した。即ち I 型は肝下面との 間に明確な腹膜の二重のひだを形成しているるの，II 型は胆震管のみで肝に付着して腹腔内に遊離している
表 1 年踣と性別

\begin{tabular}{|c|c|c|c|c|}
\hline 年令 & 男 & 女 & 不明 & 合计 \\
\hline $0 \sim 99$ & 3 & 1 & 0 & 4 \\
$10 \sim 19$ & 6 & 0 & 0 & 6 \\
$20 \sim 29$ & 2 & 0 & 0 & 2 \\
$30 \sim 39$ & 1 & 2 & 0 & 3 \\
$40 \sim 49$ & 1 & 1 & 0 & 2 \\
$50 \sim 59$ & 2 & 6 & 0 & 8 \\
$60 \sim 69$ & 3 & 22 & 0 & 25 \\
$70 \sim 79$ & 8 & 38 & 1 & 47 \\
$80 \sim 89$ & 1 & 21 & 0 & 22 \\
$90 \sim$ & 0 & 2 & 0 & 2 \\
不 明 & 0 & 0 & 4 & 4 \\
\hline & 27 & 93 & 5 & 125 \\
\hline
\end{tabular}

あのである。そして当然のことながらII型に捻枟が多 いとしている。佐々木ら ${ }^{15}$ (は本邦35例中文献的に検討 しえた26例の5ち 9 例が I 型で, 15例がII 型であった と報告している．われわれの症例るII型に属する．し かし Breawer ${ }^{16}$ によれば移動性胆震は剖検時 $5 \%$ に みられ, Hess ${ }^{17}$ は外科的手術時約 $4 \%$ にみたと述べて いる.つまり本症発生には他の因子の関与が考えられ る，その一つは老踰による全身消耗，栄養低下，体重 减少等により腹腔内脂肪組織の減少と腹腔内压の减少 が胆震の可動性を増す原因となる。これはるい震，馣 背，内䁍下垂が本疾患には多くみられることからも推 察される ${ }^{18)}$.この上に機械的因子として急激な体位変 換があげられる．石垣ら ${ }^{19}$ は前屈位における体軸を中 心とした連続的な振子様運動を捻転発生の重要な因子 としてあげている。ささらに隣接消化管の蠕動六進, 外

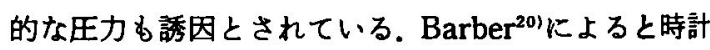
廻りの热転は胃の蠕動の影響により生ずると述べてい る，反時計方向の捻転は横行結晹の蠕動が強く関与す ると思われる。 また胆石，炎症による胆汁らっ滞との 関倸る当然推察される。本症の胆石合併頻度は

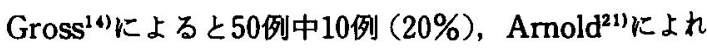
ば48例 中16例 (33.3\%), Rais ${ }^{22}$ は112例 中 31 例 (27.6\%)，また西野 ${ }^{23)}$ は40例中14例（35\%）である. Carter ら ${ }^{24)}$ は胆石および胆䨘炎を二義的なすのと速 べている.一方 Haines ら 251 は胆石, 资症か胆计うっ商 を招き，本症発生の誘因となることを指摘している. われわれの症例す 4 コの浮遊結石を認めた。

捻転方向および捻転度について, 捻転方向は Case ${ }^{26)}$ 
表 2 蛀転方向と捻転度

\begin{tabular}{|l|r|r|r|r|}
\hline 方向 & 時针 & 反時旪 & 不明 & 合尌 \\
\hline $180^{\circ}$ 以下 & 0 & 0 & 3 & 3 \\
$180^{\circ}$ & 18 & 12 & 1 & 31 \\
$270^{\circ}$ & 7 & 2 & 0 & 9 \\
$360^{\circ}$ & 39 & 14 & 2 & 55 \\
$450^{\circ}$ & 1 & 0 & 0 & 1 \\
$540^{\circ}$ & 3 & 3 & 0 & 6 \\
$720^{\circ}$ & 1 & 2 & 0 & 3 \\
$1080^{\circ}$ & 1 & 0 & 0 & 1 \\
不 明 & 0 & 0 & 16 & 16 \\
\hline 合計 & 70 & 33 & 22 & 125 \\
\hline
\end{tabular}

によると反時計方向が多いとされている，表 2 に示す 如く本邦集計例125例のうち記載の明らかな103例中70 例（68.0\%）が時計方向で多くをしめている．また捻 転度では $180^{\circ}$ 以下の不完全捻転から1,080であり， $360^{\circ}$ が103例中55例で最も多い。われわれの症例は反時 計方向に720"の捻転である.

診断では，本疾患に特有な臨床症状はなく，一般に 上腹部敫痛ではじまり，時に悪心，呕吐を伴うが，時 間が経過するにつれ発熱, 白血球增多などがみられる。 Haines ${ }^{25}$ は本疾患の 4 徽候として，1）無力性下垂体 啠の老婦人，2）急激な上腹部痛，3）腹部尰瘤の触知， 4）黄疸，発熱の欠如をあげている。また Arther ${ }^{27) は ， ~}$ 1）急性胆妻炎の症状を呈するか，発病当初は発熱，脈 拍增加は伴わない，2）黄㾞の久如，3）急速に増大す ろ胆重部の腄瘤触知をあげた。森本ら ${ }^{28)}$ の本邦報告集 計例では91例中上腹部痛が最む多く76例，次いで呕吐 59例，以下白血球増多，腹壁緊張，腫瘤触知，発熱の 順である。腫瘤触知は35例 (38.4\%)にみられ， Arnold ${ }^{21}$ は448例中19例（40\%）にみとめられたと報告 している.本症の術前診断としては表了に示すように, 本邦集計125例中胆重炎又は胆石症33例, 腹膜炎30例,

表 3 術前診断

\begin{tabular}{|c|c|}
\hline 診 & 症例数 \\
\hline 胆家炎または胆石症 & $\overline{33}$ \\
\hline 炎 & 30 \\
\hline 急性虫垂炎および穿孔 & 22 \\
\hline 性 腹 症 & 16 \\
\hline 周 -十二指腸暴痛穿孔 & 7 \\
\hline レウ & 5 \\
\hline 卵栄面腫荎捻転 & 3 \\
\hline 症 & 2 \\
\hline 不 & 7 \\
\hline
\end{tabular}

表 4 手術術式と転帰

\begin{tabular}{|c|c|c|c|c|}
\hline 街式転燸 & 治滔 & 死亡 & 不明 & 合計 \\
\hline 䏣 摘 出 術 & 88 & 10 & 7 & 105 \\
\hline 外䏣汁漠造設術 & 5 & 0 & 0 & 5 \\
\hline $\begin{array}{l}\text { 盟零墒出術およひ } \\
\text { 䍃䏣管切開術 }\end{array}$ & 1 & 0 & 0 & 1 \\
\hline 不 & 4 & 0 & 10 & 14 \\
\hline 計 & 98 & 10 & 17 & 125 \\
\hline
\end{tabular}

急性虫垂炎および穿孔22例で，術前に本症と確訩した のは 2 例であった5)6)．術前診断に際しては超音波娭 查，経皮的胆毫穿刺造影が有効である。树野ら.51は超音 波検査により胆重壁が著明に肥厚し，Freeな内部エ コー, 胆震の正中への偏位などの所見を認めらると述 べている。また吉岡ら゙は頝部の腫場エコーのような 淡いェコ一像が体位変換によってもその位膡, “形状に 全く变化なく明らかに結石と異なるエューで，この部 位で胆要内腔と総胆管との交通が遮断されていること から捻転部位であることが推察されたと報告してい る.一方経皮的胆衰穿刺造影では，梛野ら 塞管が次第に細くなり閉塞していると述べているが， 本症の胆黄は大部分が肝下面から遊離しているため， 経肝的に穿刺することの困難性と，胆表壁が壊死によ りるろくなっているために穿刺時の胆衰穿孔の危険性 を指摘している．われわれも透視下に胆垂穿刺を試み たところ，吸引した胆要胆汁が血性であったため，胆 葆内出血と診断し婜急に開腹した。確実に胆衰が穿刺 され，血性胆汁の場合は本症を疑らべきであろら。

治療扰よび予後に関してみると，胆貫捻転症は胆要 の組織壊死を伴らことから48時間以上経過した手術症 例の予後は極めて悪い26). 術式と転帰について本邦例 をみると表 4 の如く，胆摘術が不明14例を除く111例中 105例と压倒的に多いことからも手技的には容易であ る。予後をみると，本邦報告例中10例 $(9.3 \%)$ の死亡 例がみられる，好発年齢が高龄であるにもかかわらず 最近 5 年間での死亡例は報告されていない，術後管理 の発達により今日では重篤な合併㱏のないかぎり積極 的に胆摘術を施行すべきものと考える。

\section{おわりに}

われわれは最近経験した87歳女性の胆烡捻転症例を 報告するとともに，本邦報告例125例に若干の文献的考 察を加えた。

本論文の要旨は昭和57年 5 月23日第201回東海外科学会 
に於いて発表した。

\section{文嗝}

1) Wendel, A.V.: A case of floating gall-bladder and kidney complicated by cholelithiasis with perforation of the gall-bladder. Ann. Surg., 27 : 199-202, 1898.

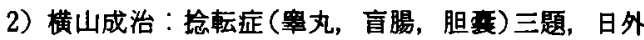
会誌, $33: 719,1932$.

3) Ashby, B.S.: Acute and recurrent torsion of the gallbladder. Brit. J. Surg., 52: 182-184, 1965.

4) Bothra, R.: Torsion of the gall-bladder in the aged. Brit. J. Surg., $60: 359-360,1973$.

5）梛野正人，七野滋彦，佐藤太一郎他：術前診断しえ た小児胆咅捻転症の 1 例，日消外会誌，15： $1269-1273,1982$.

6）吉岡正智, 宮原成子, 吉安正行他：術前診断しえた 胆衰捻轱症の 1 例, 胆と䐷、 $3: 813-819,1982$.

7）大林速雄，今城 保，守安邦之他：胆緗捻転症の1 治倹例, 外科診療, 15：1513-1518，1973.

8）安井広明, 梅本大之, 宮地道弘：胆烡軸捐の 1 治験 例, 日臨外会誌，37:53-59，1976.

9）鎌田國尋, 岡本節夫, 一色道夫他：小児胆票捻転症 の 1 例, 外科診療, $10 ： 1292-1296,1981$.

10）魚住 建, 鈴木有二,川島喜代志他：胆莗捻転症の 1 例，日臨外会誌， $43: 208,1982$.

11）佐久間 崇, 若林利重, 斉藤度一他：先天性総胆管 抬張症に合併した胆重捻転症の 1 例，日臨外会誌， 29 : $340,1967$.

12）安部拨一, 赤坂嘉宣, 高橋英秋他：95歳の胆要捻転 症の 1 治験例，日臨外会誌，85：777，1974.

13) Azmy, A., Boddy, S.A. and Eckstein, M.B.: Torsion of gallbladder, embedded an accessory lobe of liver in a neonate with Beckwith
Syndrome. Z. Kinderchir., 30 : 277, 1980.

14) Gross, R.E. : Congenital anomalies of the gallbladder. Arch. Surg., 32 : 131-162, 1936.

15）佐々木弘，菅野成弘，高橋真二：胆重埝転症の 3 例, 外科, $28 ： 437-443,1966$.

16) Breawer, G.E. : Preliminary report on surgical anatomy of the gallbladder and ducts from an analysis of one hundred dissection. Ann. Surg., 29: 721, 1899.

17) Hess, $W$.: Surgery of the biliary passages and the pancreas. Van Nostrand Co. 111, 1965.

18) Bockus, H.L.: Gastroenterology III, W.B. Saunders Co., 716, 1966.

19）石垣 宏, 原 彦夫, 能谷太郎他：胆西捻较症の 1 治悇例，外科，36：215-217，1974.

20) Barber, A.H.: Acute torsion of the gall-bladder. Br. Med. J., 2 : 1272-1273, 1939.

21) Arnold, L.: Acute torsion of the gall-bladder. Br. J. Surg., 45 : 338-340, 1958.

22) Rais, O.: Torsion of the gallbladder. Acta Chir. Scand., $113: 289,1957$.

23）西野信夫，坂口且和，新宮 雅他：胆蒜捻轱症，外 科診療， $11: 887-891 ， 1969$.

24) Carter, R., Thompson, R.J., Brennan, L.P., et al. : Volvulus of the gallbladder. Surg. Gynecol. Obstet., 116 : 105-108, 1963.

25) Haines, F.X. and Kane, J.T. : Acute torsion of the gallbladder. Ann. Surg., 128 : 253-256, 1948.

26) Case, T.C.: Acute torsion of gallbladder. Am. J. Surg., $82: 749-753,1951$.

27) Arther, H.R.: Acute torsion of the gallbladder. Br. Med. J., 2 : 265-266, 1937.

28）森本忠興, 北村宗生, 小柴 康他：胆素捻転症の 1 治悇例。外科診療, $20: 613-616,1978$. 